\begin{tabular}{|l|l|r|}
\hline A1 Fitrah & Peranan Permainan Edukatif dalam \\
\hline Journal Of Early Childhood Islamic Education & Menstimulasi Perkembangan Kognitif Anak \\
ISSN $:$ 2599-2287 & Septi Fitriana \\
Vol.1 No.2 Januari 2018 & \\
\hline
\end{tabular}

\title{
PERANAN PERMAINAN EDUKATIF DALAM MENSTIMULASI PERKEMBANGAN KOGNITIF ANAK
}

\begin{abstract}
Abstrak
Jurnal ini adalah jurnal tentang peranan permainan edukatif dalam menstimulasi perkembangan kognitif anak. Stimulasi yang baik dari pendidik akan menjadikan perkembangan anak optimal, salah satunya perkembangan kognitif. Anak membangun pengetahuannya sendiri melalui bermain. Dunia anak adalah dunia bermain yang menyenangkan, oleh karena itu dibutuhkan stimulasi yang tepat salah satunya melalui permainan edukatif. Salah satu permainan edukatif yang dapat menstimuasi perkembangan kognitif anak, yaitu smart book dan maze 3 dimensi. Permainan ini manarik bagi anak, serta menjadikan anak mampu membangun pengetahuannya sendiri.
\end{abstract}

Kata Kunci : Permainan Edukatif, Perkembangan Kognitif

Septi Fitriana
septifitriana84@yahoo.co.id
IAIN Bengkulu

\section{Pendahuluan}

\section{Pendidikan pada Anak Usia} Dini (PAUD) pada hakikatnya ialah pendidikan yang diselenggarakan dengan tujuan untuk memfasilitasi pertumbuhan dan perkembangan anak secara menyeluruh atau menekankan pada pengembangan seluruh aspek perkembangan anak. Secara institusional, pendidikan anak usia dini juga dapat diartikan sebagai salah satu bentuk penyelenggaraan pendidikan yang menitik beratkan pada peletakan dasar ke arah pertumbuhan dan perkembangan, baik koordinasi motorik (halus dan kasar), kecerdasan emosi, kecerdasan jamak (multiple intelligences) maupun kecerdasan spiritual. ${ }^{1}$ Pendidikan anak usia dini juga didirikan sebagai usaha mengembangkan seluruh aspek perkembangan anak seperti aspek nilai agama dan moral, aspek kognitif, aspek bahasa, aspek sosial emosional, aspek fisik motorik, dan aspek seni dalam rangka menjembatani pendidikan dalam keluarga ke pendidikan sekolah. $^{2}$

Berdasarkan undang-undang No 20 tahun 2003 pasal 1 ayat 14, Pengertian PAUD, yaitu; suatu upaya pembinaan yang ditujukan kepada anak sejak lahir sampai dengan usia enam tahun

\footnotetext{
${ }^{1}$ Diana Mutiah, Psikologi Bermain AUD (Jakarta: Kncana, 2010) h. 3

${ }^{2}$ Binti Maunah, Ilmu Pendidikan, (Yogyakarta: Teras, 2009), h. 6
} 


\begin{tabular}{|l|l|r|}
\hline A1 Fitrah & Peranan Permainan Edukatif dalam \\
\hline Journal Of Early Childhood Islamic Education & Menstimulasi Perkembangan Kognitif Anak \\
ISSN $:$ 2599-2287 & Septi Fitriana \\
Vol.1 No.2 Januari 2018 & \\
\hline
\end{tabular}

yang dilakukan melalui pemberian rangsangan pendidikan untuk membantu pertumbuhan dan perkembangan jasmani dan rohani agar anak memiliki kesiapan dalam memasuki pendidikan lebih lanjut. ${ }^{3}$

Dalam proses pembelajaran anak usia dini kemampuan kognitif anak sangat penting untuk dikembangkan. Karena faktor kognitif mempunyai peranan penting bagi keberhasilan anak dalam belajar, karena sebagian besar aktivitas belajar selalu berhubungan dengan mengingat dan berfikir. ${ }^{4}$ Kognitif sering disinonimkan dengan intelektual karena prosesnya banyak berhubungan dengan berbagai konsep yang telah dimilki anak dan berkenaan dengan kemampuan berfikirnya dalam memecahkan suatu masalah. $^{5}$

Oleh karena itu mengingat pentingnya peranan aspek kognitif dalam proses belajar dan pengetahuan anak, maka diperlukan suatu stimulasi permainan yang tepat bagi anak untuk mengembangkannya. Salah satu permainan yang dapat digunakan dalam upaya pengembangan kemampuan kognitif anak adalah dengan permainan edukatif. Permainan edukatif merupakan salah satu jenis permainan

\footnotetext{
${ }^{3}$ Menurut Depdinkas dalam Yuliani nuraini sujiono. Konsep Dasar PAUD. Jakarta, Indeks: 2012. H. 4

4 Mulyasa, Manajemen PAUD, (Bandung: PT

Remaja Rosdakarya, 2014) h. 25

${ }^{5}$ Ibid.
}

edukatif yang berisi tentang permainanpermainan yang mengasah kognitif anak, misalnya puzzle, bongkar pasang gambar, mengenal warna, bentuk dan pola. Adapun jenis permainan edukatif dibuat harus sesuai karakteristik Anak usia dini. Sehinga, didalamnya tidak hanya mengasah kognitif saja melainkan aspek lain juga dikembangkan melalui permainan ini.

\section{Teori Kognitif}

\section{Pengertian Kognitif}

Psikologi kognitif telah berkembang melalui beberapa fase dalam sejarah singkatnya. Sejak penelitian tentang intropeksi oleh Ebbinghaus di akhir abad 19, psikologi kognitif berkembang memasuki pengkondisian klasik, bersama Thorndike dan kemudian beralih ke behaviorisme Pavlov, Watson, dan Skinner.

Pada awalnya, paradigma kognitif menjadi terkenal melalui buku Perception and Communnication karya Donald Broadbent pada tahun 1958, kendati perkembangan-perkembangan lain seperti teori bahasa Chomsky (1956) dan penuntas umum masalah umum dari Newell dan Simon (1958) menjadi awal revolusi kognitif. Istilah 


\begin{tabular}{|l|l|r|}
\hline A1 Fitrah & Peranan Permainan Edukatif dalam \\
\hline Journal Of Early Childhood Islamic Education & Menstimulasi Perkembangan Kognitif Anak \\
ISSN $:$ 2599-2287 & Septi Fitriana \\
\hline & Vol.1 No.2 Januari 2018 & \\
\hline
\end{tabular}

“psikologi kognitif” pertama kali digunakan secara umum ketika buku Cognitive Psychology karya Ulrich Neisser dipublikasikan pada tahun 1967. Revolusi kognitif berkembang lebih lanjut pada tahun 1970-an, ditandai dengan fokus pada pendekatan komputasional yang dipelopori karya David Marr. Subjek ilmu berkembang pesat dengan mencakup fungsi-fungsi kognitif lebih tinggi yang tidak banyak diteliti pada masa itu. Konsep "struktur mental" kemudian digunakan secara luas dan hubungan dengan fisiologi dan ilmu komputer mulai terbentuk. Sejak revolusi kognitif, psikologi kognitif didominasi oleh model pemrosesan berkapsitas terbatas yang memliki fungsi umum. Tujuan psikologi kognitif adalah mengetahui bagaimana memahami struktur-struktur yang terlibat dalam kognisi, seperti penyaringan, leksikon dan penyimpanan, dan proses-proses yang bekerja pada data kognitif, termasuk pengodean, hambatan dan lupa. ${ }^{6}$

Istilah kognitif mulai banyak dikemukakan ketika teori Jean Piaget banyak ditulis dan dibicarakan lagi pada tahun 1960-an. Piaget mengemukakan bahwa perkembangan

\footnotetext{
${ }^{6}$ Jonathan Ling dan Jonathan Catling, .Psikologi Kognitif.(Jakarta:Erlangga. 2002) hlm 2
}

kognitif bukan hanya hasil kematangan organism, bukan pula pengaruh lingkungan saja, interaksi antara keduanya. Dalam pandangan ini organism aktif mengadakan hubungan dengan lingkungan. Pengertian kognisi sebenarnya meliputi aspek-aspek struktur kognitif yang fundamental dan membimbing tingkahlaku anak yang terletak pada pemahaman bagaimana pengetahuan tersebut dalam berbagai aspek.

Otak manusia bekerja menerima informasi, memprosesnya kemudian memberi jawaban. Proses jalannya informasi tersebut pada manusia disebut kognisi. Sehingga kognisi dapat diartikan sebagai suatu kegiatan atau proses memperoleh pengetahuan (termasuk kesadaran, perasaan, dan sebagainya) atau proses usaha mengenali sesuatu melalui pengalaman sendiri. Dalam psikologi kognitif, bahasa menjadi salah satu objek materialnya karena bahasa merupakan perwujudan fungsi-fungsi kognitif. ${ }^{7}$

Pengembangan kognitif dari: (a) logika matematika dengan indikator: dapat membedakan ukuran

\footnotetext{
7 Yuliani Nurani Sujiono, Metode Pengembangan Kognitif.(Tanggerang Selatan:Universitas Terbuka. 2014) hlm 3.3
} 


\begin{tabular}{|l|l|r|}
\hline & Al Fitrah & Peranan Permainan Edukatif dalam \\
Journal Of Early Childhood Islamic Education & Menstimulasi Perkembangan Kognitif Anak \\
ISSN : 2599-2287 & Septi Fitriana \\
\hline
\end{tabular}

besar dan kecil, dapat mengenal konsep angka 1-3, dapat memasang benda sesuai dengan pasangannya, dapat mengenali kegiatan di waktu: pagi, siang dan malam hari, dapat mengenal konsep makanan gizi seimbang dan mengenal konsep "terjadinya banjir” melalui percobaan sederhana, (b) visual spasial dengan indikator: dapat mengenal warna, dapat mengelompokkan sesuatu menurut warna dasar, dapat menyebutkan kembali benda-benda yang baru dilihat, dapat menyebutkan kembali urutan kegiatan, misalnya urutan kegiatan dalam menyikat. $^{8}$

Perkembangan kognitif Piaget adalah Salah satu teori yang menjelaskan bagaimana anak beradaptasi dan menginterpretasikan objek dan kejadian-kejadian disekitarnya. Bagaimana anak mempelajari ciri-ciri dan fungsi dari objek-objek, seperti mainan, perabot, dan makanan, serta objek-objek sosial seperti diri, orang tua dan teman. Bagaimana cara anak belajar mengelompokkan objek-objek untuk mengetahui persamaan-persamaan dan perbedaan-perbedaannya, untuk

\footnotetext{
${ }^{8}$ Yuliani Nurani Sujiono dan Bambang Sujiono, Bermain Kreatif Berbasis kecerdasan Jamak.(Jakarta:PT Indeks.2010) hlm 100
}

memahami penyebab terjadinya perubahan dalam objek-objek atau peristiwa-peristiwa, dan untuk membentuk perkiraan tentang objek dan peristiwa tersebut.

Piaget percaya bahwa pemikiran anak-anak berkembang menurut tahaptahap atau periode-periode yang terus bertambah kompleks. Piaget juga meyakini bahwa pemikiran seorang anak berkembang melalui serangkaian tahap pemikiran dari masa bayi hingga masa dewasa. Kemampuan bayi melalui tahap-tahap tersebut bersumber dari tekanan biologis untuk menyesuaikan diri dengan lingkungan (melalui asimilasi dan akomodasi) serta adanya pengorganisasian struktur berfikir. Tahap-tahap pemikiran ini secara kualtatif berbeda pada setiap individu. Demikian juga, corak pemikiran seorang anak pada satu tahap berbeda dari corak pemikirannya pada tahap lain. tahap-tahap perkembangan pemikiran ini dibedakan Piaget atas 4 tahap, yaitu sebagai berikut: ${ }^{9}$

a. Sensori motor (0-2 tahun)

Pada tahap ini bayi bergerak pada tindakan refleks insting pada

\footnotetext{
9 Rini Hildayani, Psikologi Perkembangan Anak.(Jakarta: Universitas terbuka. 2009) hlm 3.53.23
} 


\begin{tabular}{|l|l|r|}
\hline A1 Fitrah & Peranan Permainan Edukatif dalam \\
\hline Journal Of Early Childhood Islamic Education & Menstimulasi Perkembangan Kognitif Anak \\
ISSN $:$ 2599-2287 & Septi Fitriana \\
\hline & Vol.1 No.2 Januari 2018 & \\
\hline
\end{tabular}

saat lahir sampai permulaan pemikiran simbolis. Bayi membangun suatu pemahaman tantang dunia melalui pengkoordinasian pengalamanpengalaman sensor dengan tindakan fisik.

b. Pra Operasional (2-7 tahun)

pada tahap ini anak mulai mempresentasikan dunia dengan kata-kata dan gambar-gambar. Hal ini menunjukan adanya peningkatan pemikiran simbolis dan melampaui hubungan informasi sensor dan tindak fisik.

c. Operasional Konkret (7-11 tahun)

pada tahap ini anak dapat berpikir secara logis mengenai peristiwa-peristiwa yang konkret dan mengklasifikasikan bendabenda kedalam bentuk-bentuk yang berbeda.

d. Operasional Formal (11-15 tahun)

pada tahap ini anak mampu berfikir denga cara yang lebih abstrak dan logis. Pemikirannya menjadi lebih idealistik.

Berdasarkan penjelasan di atas dapat disimpulkan bahwa perkembangan kognitif adalah suatu pemikiran yang dimiliki oleh setiap orang yang akan semakin berkembang sesuai dengan kejadian yang ada disekitarnya dengan tahap proses yang sesuai dengan usia mereka, perkembangan kognitif terdiri dari berbagai tahapan seperti skema, adaptasi, organisasi dan penyimpanan informasi serta kemampuan memperoleh pengetahuan, berpikir dalam menyelesaikan masalah, sebab akibat.

\section{Teori Perkembangan Kognitif Piaget} dan Vygotsky

Menurut Piaget seorang anak akan memperoleh banyak dan lebih banyak lagi skema, baik dari situasi yang sudah biasa ia kenal maupun situasi yang baru. Dalam prosesnya anak akan menyaring skema-skema yang mereka miliki dan mulai menggunakan skema individual yang dimiliki oleh setiap orang yang akan diintegrasikan ke dalam sistem proses mental yang lebih luas atau orang akan diintegrasikan ke dalam sistem proses mental yang lebih luas atau disebut juga sebagai operasi (opration).

Dalam pandangan Vygotsky dialog dengan orang lain merupakan kondisi yang mendasar untuk meningkatkan perkembangan kognitif. Dari dialog ini, secara bertahap anak akan memasukkan (menggabungkan) 
cara berfikir dan memahami dunia yang akan dilakukan bersama dengan orang dewasa atau teman lain yang lebih berpengaruh. Proses aktivitas sosial berkembang menjadi aktivitas mental internal disebut sebagai internalisasi. $^{10}$

Dapat disimpulkan teori perkembangan kognitif Piaget dan Vygotsky adalah menurut Piaget tahapan perkembangan kognitif anak sensorimotor 0-2 tahun, praoperasional 2-7 tahun, operasonal konkrit 7-12 tahun, dan operasional formal 12 tahun ke atas sedangkan menurut Vygotsky perkembangan sosial mempengaruhi perkembangan kognitf anak.

\section{Karakteristik}

Perkembangan

\section{Kognitif anak}

$$
\text { Lingkup perkembangan }
$$

kognitif meliputi pengetahuan umum dan sains, konsep bentuk, warna, ukuran dan pola, konsep bilangan, lambang bilangan an huruf. Sedangkan karakteristik perkembangan kognitif anak usia dini adalah sebagai berikut: ${ }^{11}$

a) Menyempurnakan huruf atau suku kata.

\footnotetext{
${ }^{10}$ Rini Hildayani, Psikologi Perkembangan Anak.(Jakarta: Universitas terbuka. 2009) hlm 3.5-3.23

${ }_{11}$ Yuliani Nurani Sujiono, Metode Pengembangan Kognitif.(Tanggerang Selatan:Universitas Terbuka. 2014) hlm 2.182.19
}

b) Menyempurnakan kalimat dan mengisi titik-titik.

c) Menceritakan kegiatan berdasarkan gambar dan membaca percakapan.

d) Membaca angkat 1-10

e) Menyapa dengan tutur kata sopan

f) Membangun kemampuan pendengaran untuk membedakan bunyi-bunyi huruf yang terpisah.

g) Mencocokkan bunyi huruf awal dengan gambar.

h) Mengelompokkan benda

i) Mencocokkan gambar

j) Memahami konsep bangun ruang, konsep luas dan konsep waktu.

Dapat disimpulkan karakteristik perkembangan kognitif, yaitu; pengetahuan umum dan sains, konsep bentuk, warna, ukuran dan pola, konsep bilangan, lambang bilangan dan huruf.

\section{Proses Perkembangan Kognitif}

Proses yang membangun pengetahuan anak merupakan pertumbuhan kognitif yang terjadi melalui empat proses dan saling berhubungan, yaitu: ${ }^{12}$

a) Skema

Piaget mengatakan bahwa ketika seorang anak mulai membangun

\footnotetext{
12 Yuliani Nurani Sujiono, Metode Pengembangan Kognitif.(Tanggerang
} Selatan:Universitas Terbuka. 2014) hlm 3.4-3.5 


\begin{tabular}{|l|l|r|}
\hline A1 Fitrah & Peranan Permainan Edukatif dalam \\
\hline Journal Of Early Childhood Islamic Education & Menstimulasi Perkembangan Kognitif Anak \\
ISSN $:$ 2599-2287 & Septi Fitriana \\
Vol.1 No.2 Januari 2018 & \\
\hline
\end{tabular}

pemahaman tentang dunia, otak yang berkembang pun membentuk skema. Ini merupakan tindakan atau representasi mental yang mengorganisasikan pengetahuan.

b) Adaptasi

Adaptasi adalah istilah Piaget untuk cara anak memperlakukan informasi baru dengan mempertimbangkan apa yang telah mereka ketahui. Adaptasi meliputi dua langkah, yakni:

Asimilasi, terjadi ketika anak-anak memasukkan informasi baru kedalam skema-skema yang ada.

Akomodasi, terjadi ketika anak-anak menyesuaikan skema-skema mereka dengan informasi dan pengalamanpengalaman baru.

c) Organisasi

\section{Organisasi} adalah pengelompokan perilaku-perilaku dan pemikiran-pemikiran yang terisolasi ke dalam sistem yang lebih teratur dan lebih tinggi.

d) Ekulibrasi/Penyimpangan

Ekulibrasi merupakan suatu mekanisme yang diajukan Piaget untuk menjelaskan bagaimana anak-anak berpindah dari satu tahapan pemikiran ke tahapan pemikiran berikutya. Perpindahan ini terjadi karena anak mengalami konflik kognitif atau disequilibrum, dalam usahanya memahami dunia.

\section{Teori Bermain}

\section{Pengertian bermain}

Anak selalu memerlukan bermain, karena saat bermain gelombang alfa anak mencapai $100 \%$. Kegiatan yang menyenangkan, tanpa paksaan dari siapapun membuat potensi anak berkembang optimal. Anak belajar melalui bermain, sebab melalui bermain anak mengerti banyak hal. Dalam bermain harus distimulasi menggunakan alat permainan yang harus disiapkan oleh orang tua dan guru.

Bermain adalah setiap kegiatan yang dilakukan untuk memperoleh kesenangan, tanpa mempertimbangkan hasil akhir. Bermain adalah kegiatan yang dilakukan secara sukarela tanpa paksaan atau tekanan dari luar. Dalam bermain tidak ada peraturan lain kecuali yang ditetapkan permainan itu sendiri. $^{13}$

Dalam pengertian lain bermain juga bisa didefinisikan sebagai suatu aktivitas yang membantu anak

\footnotetext{
13 Brooks dan Elliot dalam Soemiarti patmonodewo, Pendidikan Anak Prasekolah, (Jakrata: Rhineka Cipta, 2008), h.101
} 


\section{Al Fitrah Journal Of Early Childhood Islamic Education ISSN : 2599-2287 \\ Vol.1 No.2 Januari 2018}

mencapai perkembangan yang utuh, baik fisik, intelektual, sosial, moral dan emosional. ${ }^{14}$

Adapun ciri-ciri dalam bermain yaitu:

a. Aktif, hampir pada semua permainan anak aktif, baik secara fisik maupun psikis. Anak melakukan eksplorasi, investigasi, ekperimen, dan ingin tahu tentang orang, benda, ataupun kejadian.

b. Menyenangkan, kegiatan bermain tampak sebagai kegiatan untuk bersenang-senang. Anak-anak tertawa, berteriak lepas, dan ceria seakan tidak memiliki beban hidup.

c. Motivasi intrinsik, bermain dimotivasi dari dalam diri anak, karena itu dilakukan bukan karena adanya tuntunan masyarakat atau fungsi-fungsi tubuh.

d. Memiliki aturan, setiap permainan ada aturannya. Anak-anak harus menaati peraturan itu demi tercainya permainan yang menarik dan terhindar dari konflik.

e. Simbolis dan berarti, pada saat bermain, anak menghubungkan antara pengalaman lampaunya dengan kenyataan yang ada. Bermain memungkinkan anak

14 Utami Munandar dalam Soemiarti patmonodewo, Pendidikan Anak Prasekolah, h.101
Peranan Permainan Edukatif dalam Menstimulasi Perkembangan Kognitif Anak

Septi Fitriana

menggunakan berbagai objek sebagai symbol dari benda atau orang lain sehingga disebut simbolis. Peran-peran yang dimainkan anak biasanya meniru peran orang dewasa dalam masyarakatnya sehingga kegiatan tersebut sangat berarti.

f. Memiliki kelenturan, bermain memerlukan kelenturan. Kelenturan ditujukan baik dalam bentuk maupun Dalam hubungan serta

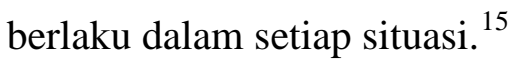

Dapat disimpulkan pengertian bermain adalah suatu kegiatan yang menyenangkan, tanpa paksaan, tanpa mempertimbangkan hasil akhir yang dilihat dari proses bukan hasil.

\section{Tahapan \\ dan}

\section{Perkembangan Bermain}

Anak bermain memilik beberapa tahap yang sesuai dengan umur mereka. Menurut Parten merupakan tokoh yang mengamati perkembangan bermain pada anak. Ia berpendapat bahwa pola perkembangan bermain menggambarkan pula perkembangan sosial anak. Adapun tahap

${ }^{15}$ Slamet Suyanto, dasar-dasar Pendidikan Anak usia Dini, (Yokyakarta: Hikayat Publizing, 2005), h. $117-118$ 


\begin{tabular}{|l|l|r|}
\hline & Al Fitrah & Peranan Permainan Edukatif dalam \\
Journal Of Early Childhood Islamic Education & Menstimulasi Perkembangan Kognitif Anak \\
ISSN : 2599-2287 & Septi Fitriana \\
\hline
\end{tabular}

perkembangan bermain anak menurut parten yaitu: $^{16}$

\section{a. Unoccupied Play}

Pada tahap ini, anak hanya melihat anak lain bermain, tetapi tidak ikut serta dalam kegiatan bermain tersebut. Pada tahap ini anak hanya mengamati sekeliling ruangan, anak yang sedang bermain dan berjalan, tetapi tidak ada interaksi dengan anak yang sedang bermain tersebut.

\section{b. Solitary Play}

Pada mulanya anak asik bermain sendiri (soliter play). Sifat egosentrisnya yang tinggi menyebabkan anak bermain sendiri dan tidak peduli dengan apa yang dimainkan oleh teman yang ada disekelilingnya. Ia hanya berfokus dengan mainannya sendiri tanpa perduli dengan hal-hal lainnya. Tahap ini terjadi di usia 2-3 tahun.

\section{c. Onlooker Play}

Tahap ini terjadi ketika anak melihat temannya bermain, anak berbicara dan menanyakan apa yang sedang mereka mainkan, namun tidak ikut dalam kegiatan permainan.

\footnotetext{
${ }^{16}$ Slamet Suyanto, dasar-dasar Pendidikan Anak usia Dini, (Yokyakarta: Hikayat Publizing2005), h. 122
}

\section{d. Parallel Play}

Pada tahap ini anak bermain terpisah dengan anak-anak lainnya. Namun mereka bermain dengan mainan yang sama kemudian meniru cara temannya bermain.

\section{e. Assosiative Play}

Tahap ini terjadi ketika permainan melibatkan interaksi sosial dengan sedikit organisasi. Mereka cenderung tertarik dan terjadi tukar-menukar mainan. Contohnya, ada dua anak yang sedang bermain bersama kemudian menukar mainan milik mereka masing-masing.

\section{f. Cooperative Play}

Pada tahap ini anak bermain bersama dengan temannya dalam sebuah kelompok kecil. Mereka mulai bisa berinteraksi dan menyesuaikan diri dengan temantemannya.

\section{g. Bermain dengan Aturan}

Pada tahap ini anak bermain bersama dengan temannya dengan bentuk tim atau kelompok. Mereka menentukan jenis permainan apa yang akan mereka mainkan, mereka juga membicarakan mengenai aturan dalam permainan, 


\begin{tabular}{|l|l|r|}
\hline A1 Fitrah & Peranan Permainan Edukatif dalam \\
\hline Journal Of Early Childhood Islamic Education & Menstimulasi Perkembangan Kognitif Anak \\
ISSN $:$ 2599-2287 & Septi Fitriana \\
\hline & Vol.1 No.2 Januari 2018 & \\
\hline
\end{tabular}

pembagian peran dan siapa yang

akan main lebih dulu.

Dapat disimpulkan tahapan

bermain yaitu, unoccupied play, solitary play, onlooker play, parallel play, assosiative play, cooperative play, bermain dengan aturan

\section{Permainan Edukatif Yang Menstimulasi Kognitif Anak}

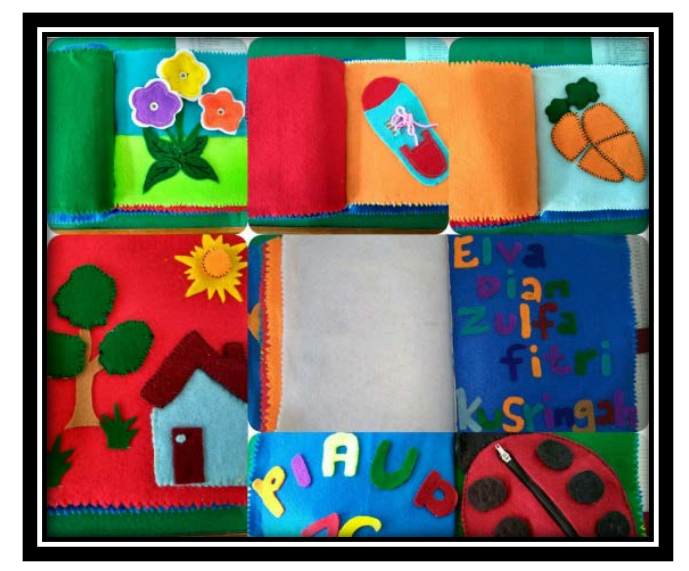

Gambar 1. Smart Book

Smart Book atau "pinter buku" itu merupakan dua gabungan kata ari Smart dan Book. Smart itu sendiri secara bahasa berarti pintar, cerdas sedangkan book berarti buku. Maka secara bahasa dapat didefinisikan smart book adalah buku pintar/cerdas. Sedangkan dalam pengertian cukup luas smart book ini merupakan media atau alat peraga yang digunakan untuk belajar mengajar dalam rangka meningkatkan kecerdasan siswa. Smart Book dalam jurnal ini merupakan salah satu jenis alat permainan edukatif yang sengaja dibuat untuk anak usia 4-5 tahun. Adapun tujuan dari APE ini adalah untuk meningkatkan kemampuan kognitif anak, dalam memecahkan masalah.

Langkah-langkah dalam membuat desain buku, pemililihan warna kain flanel, tema dan isi dari buku tersebut. Adapun desain buku tersebut dibuat dari kain flanel berukuran 10 x 15 CM dengan isi materi permainnan yang berjumlah 5 permainan. Halaman pertama dibuat dengan tema Binatang yaitu kumbang yang memiliki 6 bulatan hitam di tubuhnya yang dapat dibongkar pasang. Halaman ke dua adalah tema lingkunganku yaitu pola Rumah dan halaman yang dapat dibongkar pasang juga. Pada halaman ketiga adalah tema tanaman, yaitu bunga yang dapat 


\begin{tabular}{|l|l|r|}
\hline A1 Fitrah & Peranan Permainan Edukatif dalam \\
\hline Journal Of Early Childhood Islamic Education & Menstimulasi Perkembangan Kognitif Anak \\
ISSN $:$ 2599-2287 & Septi Fitriana \\
Vol.1 No.2 Januari 2018 & \\
\hline
\end{tabular}

dibongkar pasang juga dengan desain warna yang menarik. Halaman empat adalah tema buah yaitu wortel yang dibuat dalam bentuk Puzzle. Dan halaman kelima adalah tema kebutuhanku yaitu sepatu, dimana anak belajar mengikat tali sepatu.

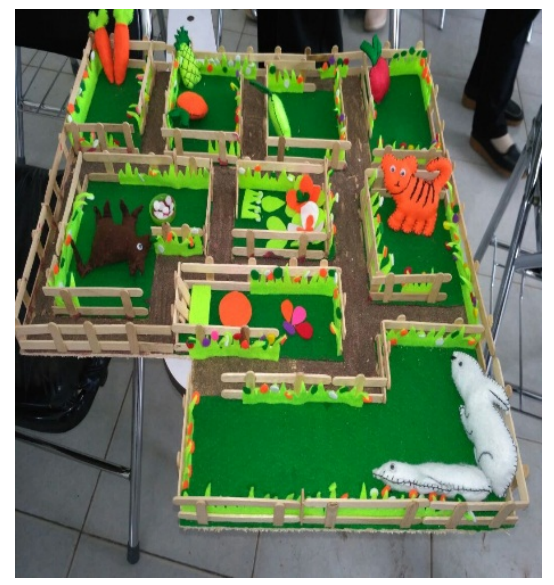

\section{Gambar 2. Mazze Tiga Dimensi}

Mazze tiga dimensi, dapat menstimulasi kognitif anak, karena Adams menyatakan bahwa permainan edukatif dalam semua bentuk permainan yang dirancang untuk memberikan pengalaman pendidikan atau pengalaman belajar kepada para pemainnya. Salah satunya adalah tekhnik maze 3 dimensi, teknik maze 3 dimensi adalah permainan yang sudah tidak asing di telinga kita. maze 3 dimensi adalah jaringan jalan yang rumit dan berliku-liku. Sebuah puzzle dalam bentuk percabangan jalan yang kompleks dan memliki banyak jalan buntu.
APE maze adalah alat yang memiliki bentuk-bentuk dengan tujuan agar orang-orang yang memainkan bisa menemukan tempat yang dituju dengan mencari jejak dan dengan menorehkan coretan. Dengan menggunakan APE maze anak bisa melatih otot-otot kecil, seperti keterampilan menggunakan jarijemari tangan dan pergelangan tangan yang tepat.

Bermain maze, dapat mengasah kemampuan anak untuk mengetahui ruang-ruang, jalur-jalur yang dilewati dan mengetahui lokasinya dalam kesatuan utuh maze tersebut. Di 


\begin{tabular}{|l|l|r|}
\hline A1 Fitrah & $\begin{array}{r}\text { Peranan Permainan Edukatif dalam } \\
\text { Journal Of Early Childhood Islamic Education } \\
\text { ISSN }: \text { 2599-2287 }\end{array}$ \\
Vol.1 No.2 Januari 2018 & Menstimulasi Perkembangan Kognitif Anak \\
\hline
\end{tabular}

Taman Kanak-kanak, permainan maze dalam bentuk 3 dimensi sudah diaplikasikan agar anak dapat mempertajam dan mengembangkan kemampuannya. Selain itu teknik maze juga dapat meningkatkan kreativitas, karena teknik maze menyediakan jalurjalur yang menarik dengan gambar dan warna yang memenuhi selera yang bisa digunakan.

Jadi maze 3 dimensi adalah permainan yang berbentuk gambar nyata, dengan pola-pola yang menarik untuk mengasah dan mempertajam perkembangan kognitif anak. selain itu dapat juga meningkatkan beberapa aspek perkembangan lainnya.

\section{Peranan Permainan Edukatif Dalam}

\section{Menstimulasi Perkembangan Kognitif}

Anak

Tanpa bermain dunia anak menjadi hampa. Perkembangan anak akan optimal jika distimulasi secara tepat. Sesuai dengan karakteristik anak bermain mempunyai banyak manfaat salah satunya mengembangkan kognitif/intelektual anak.
Adapun manfaat bermain dapat mengembangan aspek perkembangan kognitif yaitu: ${ }^{17}$

Menurut Piaget, anak belajar memahami pengetahuan dengan berinteraksi melalui objek yang ada disekitarnya. Bermain memberikan kesempatan kepada anak untuk berinteraksi dengan objek. Anak memiliki kesempatan menggunakan inderanya, seperti menyentuh, mencium, melihat, dan mendengarkan untuk mengetahui sifat-sifat objek tersebut. Dari pengindraan tersebut anak memperoleh fakta-fakta, informasi, dan pengalaman yang menjadi dasar untuk berfikir abstrak. Jadi bermain menjembatani anak dari berfikir kongkrit ke berfikir abstrak. Vygotsky menyatakan bahwa, pada saat bermain, pikiran anak terbebas dari situasi kehidupan kehidupan nyata yang menghambat anak berfikir abstrak. Penelitian Hoorn (1993) menunjukkan bahwa bermain memiliki peran yang sangat penting dalam mengembangkan kemampuan berfikir logis, imajinatif dan kreatif.

Permaianan edukatif untuk meningkatkan kemampuan memecahkan

\footnotetext{
${ }^{17}$ Slamet Suyanto, dasar-dasar Pendidikan Anak usia Dini, (Yokyakarta: Hikayat Publizing, 2005), h.122
} 


\begin{tabular}{|l|l|r|}
\hline A1 Fitrah & $\begin{array}{r}\text { Peranan Permainan Edukatif dalam } \\
\text { Journal Of Early Childhood Islamic Education } \\
\text { ISSN }: \text { 2599-2287 }\end{array}$ \\
Vol.1 No.2 Januari 2018 & Menstimulasi Perkembangan Kognitif Anak \\
\hline
\end{tabular}

masalah anak usia 4-5 tahun terlihat bahwa kemampuan kognitif anak dapat berkembang dengan baik. Pembelajaran yang mengasah kognitif anak baik berupa mengenal warna, pola, bentuk, sebab-akibat dan sebagainya. Selain hal tersebut anak-anak terlihat sangat antusias dalam melakukan permainan tersebut, karena buku tersebut didesain khusus untuk anak usia dini dan sesuai karakteristik anak usia 4-5 tahun.

Sedangkan apabila dilihat dari manfaat permainan edukatif anak-anak terlihat sangat aktif bermain dan antusias. Karena anak-anak dapat belajar mandiri dalam membongkar pasang permainan yang terdapat di buku tersebut. Anak-anak juga belajar uji coba dalam memilih pilihan pengetahuannya dalam memecahkan masalah permainan tersebut. Hal ini tentu sangat mengasah kemampuan kognitif anak.

\section{Kesimpulan Dan Saran}

\section{Kesimpulan}

Berdasarkan pembahasan di atas maka dapat disimpulkan bahwa peranan permainan edukatif sangat penting dalam mengembangkan kognitif anak khususnya dan seluruh aspek lainnya baik nilai agama dan moral, sosial emosonal dan kemandirian, fisik motorik, bahasa dan seni. Hal ini karena melalui bermain anak membangun pengetahuannya sendiri, belajar menyelesaikan masalah yang dilihat dari proses menyenangkan tanpa mementingkan hasil akhir dari kegiatan tersebut.

\section{Saran}

Dari pemaparan jurnal ini kami menyarankan kepada para pembaca untuk dapat mempraktikan dan mengimplementasikan alat permaianan edukatif ini dengan baik. Sebaiknya guru dalam menstimulasi perkembangan anak menggunakan permainan. Selain itu mampu melatih kreatifitas guru dalam belajar mengajar dan membuat APE.

\section{Daftar Pustaka}

Hildayani, Rini .2009. Psikologi Perkembangan Anak. Jakarta: Univetsitas terbuka.

Ling , Jonathan dan Jonathan Catling, .2002. Psikologi Kognitif. Jakarta:Erlangga

Maunah, Binti. 2009. Ilmu Pendidikan. Yogyakarta: Teras

Mulyasa.2014.

Manajemen PAUD.Bandung: PT Remaja Rosdakarya

Mutiah, Diana.2010. Psikologi Bermain AUD . Jakarta: Kncana 
Nurani, Yuliani dan Sujiono.2014. Metode

Pengembangan Kognitif.

Tanggerang

Selatan:Universitas Terbuka

Patmonodewo, Soemiarti. Pendidikan

Anak Prasekolah, (Jakrata:

Rhineka Cipta, 2008

Sujiono Yuliani Nurani dan Bambang Sujiono. 2010. Bermain Kreatif Berbasis kecerdasan Jamak. Jakarta:PT Indeks.

Sujiono, Yuliani nuraini. Konsep Dasar PAUD. Jakarta, Indeks: 2012.

Sujiono, Yuliani Nurani. Metode Pengembangan Kognitif.

Tanggerang

Selatan:Universitas Terbuka. 2014.

Suyanto, Slamet. Dasar-dasar Pendidikan Anak usia Dini. Yokyakarta: Hikayat Publizing, 2005. 